\title{
全自動巻取包装機の現状
}

川之汇造機株式会社 営業部 小笠原武

\section{Current Situation of Fully Automatic Random Roll Wrapping Machine}

\section{Takeshi Ogasawara}

Finishing Machine Sales Engineering, Kawanoe Zoki Co., Ltd

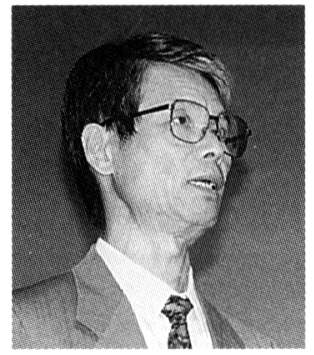

The wrapping process, which is the final finishing process for rolls (products), must meet the needs of a larger wrapping volume and a larger variety of wrapping specifications than ever before. As production control in the entire plant becomes computerized, roll wrapping machines also receive wrapping data on-line, paving the way for automatic wrapping to process a large volume and a large variety of specifications. Now we have developed a roll wrapping machine that can process rolls produced by several paper machines, by increasing its wrapping capacity as well as enabling it to follow a large variety of wrapping specifications.

This machine consists of a bar code reader, inkjet printer, wrapping machine, and labeler. Operation data for each part can be set or changed easily through a touch panel. The operator training will be completed in a relatively short time.

This machine has demonstrated high reliability as equipment that plays an important role in the final finishing process for rolls.

分類： $\mathrm{O}_{7}$ 包装, $\mathrm{O}_{1}$ 仕上一般

\section{1.はじめに}

近年, 洋紙ロールの生産は大型化, 高速化, 合理化, そして集約化された抄紙機で大量生産されている。ま た, 多種中量生産を行う場合の抄紙機には, 品種対応 のフレキシビリティ, 省力化, 省人化が要求される。

どちらの場合に打いても，抄紙機のリールからワイ ンダーへの原反搬送，空スプール返却，スリット幅替 え, 製品テールカット, 紙管供給, テールシール, 製 品搬送ライン自動化, データのバーコード処理などに より多種, 多量の巻取ロールが効率よく生産されてい る。

これら多種, 多量及び中量のロールを効䍃よく生産
するために，工場全体の生産ラインをコンピュータで 結び, 抄紙機, ワインダー, 各搬送設備, 印字機, 巻 取包装機, 胴マーキング装置, ラベル貼り機まで各製 品データをコンピュー夕管理, 通信し, 必要な個々の ロールデータを取り出せるようになってきている。卷 取ロール包装機はただ単にロールの包装を行うだけの 設備であるとは定義できなくなってきている。

当社は巻取包装機開発に着手後 30 数年経過してい るが, 紙種の多様化, 設備の高速化, 合理化, 省力化, FA 化により巻取包装機も急速に改善されてきた。

そして, 現在に至っては包装機に対する要求が二分 化されてきている。一つは多本数処理で且つ多種類対 応の自動機種, 他方は中量数処理で少種類対応の自動 
機である。参考までに多本数処理, 多種類対応機では 160 本/時, 製品径 8 種類, 幅 6 種類の処理であり, 中量数処理, 少種類対応機では 50 本/時, 製品径 2 種 類, 幅 4 種類が一般的である。なお中量数処理機に於 いては既設機の更新となる場合が多く，設置スペース が小さいことが条件となる。いずれに於いても複数の
抄紙機から仕上げられたロールを一カ所にまとめ, 一 台の自動包装機で処理することが可能である。

これらのことから, 巻取包装機設備がライン全体の 生産に直接影響するため, 信頼性が高く, 実績が豊富 な設備の検討，採用が望ましい。
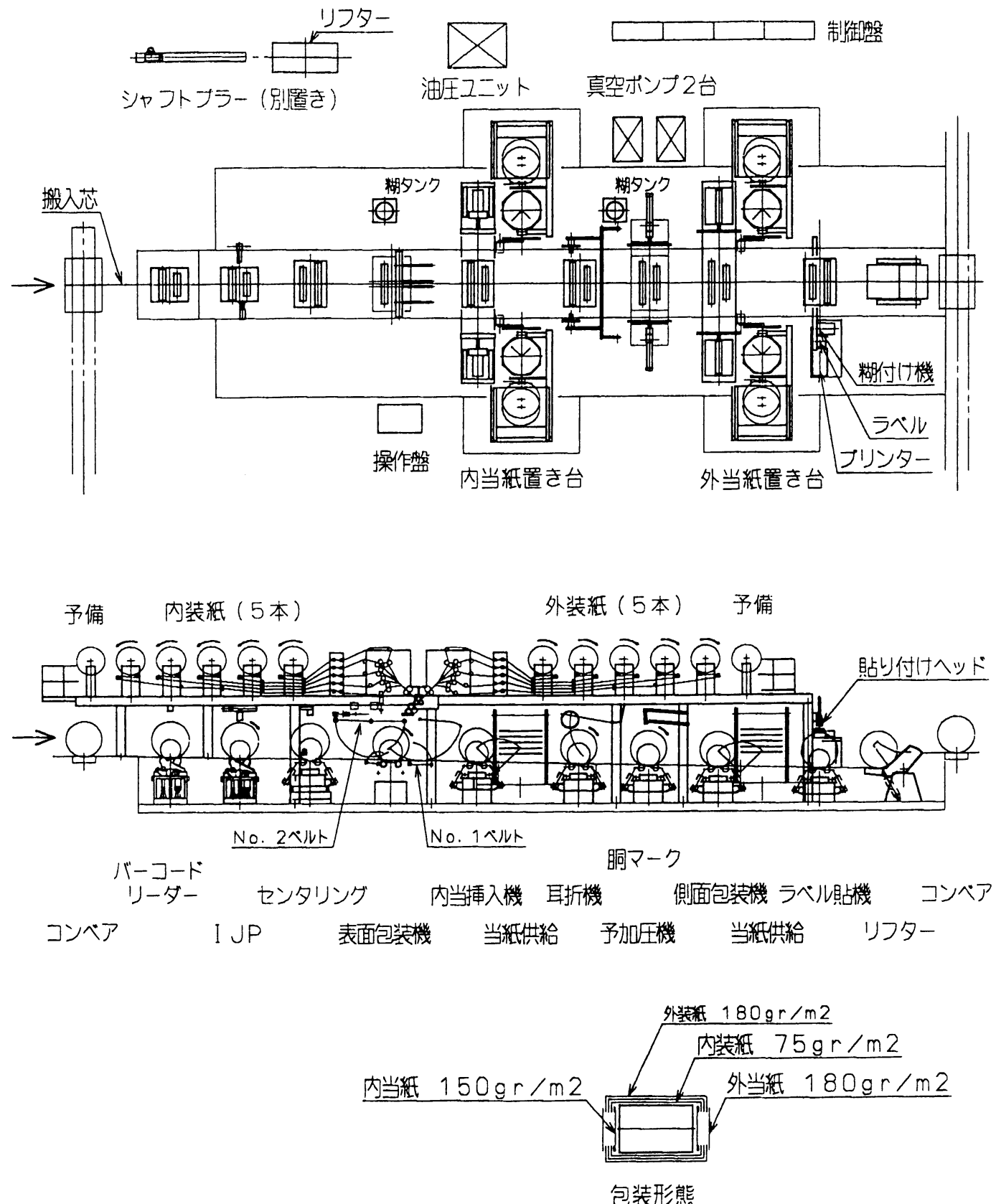

図 1 巻取包装機構成図 


\section{2. 巻取ロール包装機の構成}

\section{1 概 要}

図 1 に巻取包装機の構成図を示す。 本機は, 巻取ロール（製品）の包装を自動で行う装置 ありで, 製品寸法変化に対応させるべく, 機械, 装置 のみならず，電気関係（ソフト，デー夕）の処理をも 含めたメカトロニクスの集合体として設計されている。 また, 長年の経験に基づいて, 安全性, 使い易さにつ いても考慮がなされている。

ワインダーで仕上げられた製品に，ロールNo.，製 品の種類, 包装の形態等のデータが加えられ（バーコ ードラベルを貼付け)，搬送される。

各ワインダーから巻取包装機の入り口までの搬送は, コンベアーで行われる。

巻取包装機では, 製品のデー夕を読み取り（バーコ ードを読む), 上位コンピュータより製品のデー夕を 取り达み, 製品の計重, 端面印字, 製品包装, 胴マー キング, ラベル貼りが自動で行われ, 最終出荷製品と して搬出される。

\section{3. 巻取包装機各パートの説明}

3.1 バーコード読み取りパート

今まで伝票により手入力で製品管理をしていたが, ワインダー搬出の際, 製品胴部にバーコードラベルを 貼付けて搬送する。このバーコードを読み取り, 必要 なデータを上位コンピュータとの通信ネットで受信し， このデータは各々の機械にトラッキングしていく。こ の方法が採用されて, 各々の機械, 装置の自動化が急 速に進んだ。

\section{2 製品計重パート}

搬入された製品を 1 本毎計重を行う。計重值デー夕 は上位コンピュータへ実績として送信する。計重機は ロードセル方式の計重機を使用している。

\section{3 端面印字パート}

データにより, 製品の端面に, 製造日, ロール No. 等を印字する。印字はゴム印で自動捺印する装置とイ ンクジェットプリンター（IJP）で端面印字を行う装 置があるが, 現在はIJP で行う装置が増えてきている。 又, 製品別にインクの色分けを行うことも, ヘッドを 増やすことにより簡単にできるようになった。

IJP 装置の場合, 衝撃に弱いという久点があるが, サーボモータ制御によるソフトスタート, ソフトスト ップにより衝撃を少なくし, プリンター自身を高速で 移動しても印字が正確にまた文字の乱れもなく行える ようになっている。
また，印字データのオンラインや客先の印字フォー マットにもこのソフトウェアにより, 多種多様に柔軟 に対応できるようになった。

\section{4 胴巻きパート}

包装形態は製品によりさまざまであるが，代表的な 包装形態は防湿紙 1.3 1.5 巻外装紙 3.0 3.5 巻であ る。製品により外装紙のみで包装する場合もある。

\subsection{1 アンリールスタンド}

アンリールスタンドでは，防湿紙（内装紙）・外装 紙のスタンドを設置するのが一般的であるが，外装紙 のみで包装する場合は内・外装スタンド兼用で包材を 掛けることもできる。最大スタンド数は $6 \times 2=12$ ス タンドである。

包材繰り出し時の運転ブレーキ圧, 停止ブレーキ生は 内装紙, 外装紙（包材）の径を測定し, 包材巾と径と を感知することによりブレーキ压をコントロールし， 安定した繰り出しが行われるようにしている。また， ブレーキ制御範囲を各スタンド每にタッチパネルで変 更できるようにしている。

\subsection{2 デカーラ装置}

包材が巻芯近くになると, 卷きぐせのために包装工 程で, 種々のトラブル（紙詰まり, シワ等）が発生し やすくなるが, デカーラ装置で卷きぐせを矯正するこ とにより，トラブルを解消し巻芯近くまで使用するこ とができる。

\subsection{3 糊付け装置}

糊付け装置では, 包材の巻数に合わせ，包材終端部 に糊付けを行う。糊付けは全巾糊付けロールで転写法 を使用するため，包材に合わせ，ドクターで糊巾を決 め, 包材の耳部には糊を付けず中央部のみ糊を転写し, 製品端面を污さないよう，工夫している。糊付けは， 始めは薄く糊付けしテールエンドで, 厚く糊付けする ように制御している。一般的な糊付け長さは, 1 1.2 巻を薄く付け, 最終 0.2 卷を厚く付ける。テールエン ドのみに糊付けした場合は, 1 枚の包材強度しか得ら れず，輸送工程で裂けやすく，トラブルの原因となる が, 1 巻糊付けすることにより包材が 2 枚分の強度を 得ることとなり裂けにくくなるため, トラブルの原因 を少なくすることができる。

糊付け長さ, 糊付量の増減は, タッチパネルにより変 更できるようにしている。

\subsection{4 胴巻装置}

2 本の受ロールで製品を回転させながら，フィード ロールから繰り出された包材を, 2 組のベルトで保持 し，先端部に糊付けすることなく，製品に巻き付け所 定の巻長さが繰り出されると, マシンを停止すること 
なくロータリーカッターで包材を切断し，テールエン ドに糊付しながら胴卷する装置である。

製品の大径から小径, 大巾から小巾と包装仕様が多 様化するようになり, 胴巻付け強さ, シワ発生等の問 題が出てきたが, フィードロール速度と受ロール速度 を製品の種類により速度制御することで, 安定した胴 巻きが行えるようになった。

速度制御, 卷数等の包装プログラム, 複数の巻方法 等は夕ッチパネルにより変更できるようにしている。

\section{5 内当供給パート}

内当紙を製品の端面部に挿入する装置で, 内当紙は クラフトライナー, ラミネート紙, 段ボール+ラミネ 一ト紙貼付け品, 段ボール等の包材を供給することが できる。

内当紙挿入円板は, 製品径に応じて伸縮させること により，内当紙捜入時，胴巻包材内周に添うように円 板径の位置決めを行う。

内当紙供給装置は, 回転テーブル式, 移動テーブル 式, 棚式の型式があり, 処理能力, 設置場所により組 み合わせができる。最近では，巻取包装機内部にあっ たテーブルを, 外部に出し, 運転中でも内当紙の取替, 補給が安全に行えるようになり，卷取包装機の稼働率 を下げることなく，運転できるようになっている。ま た，この型式は棚数を増やすことにより，多くの径の 違った製品を同時搬入しても, 自動選択され，複数の 抄紙機で生産される多種類製品を一箇所にまとめ包装 することも叮能にした。

\section{6 耳折りパート}

胴巻及び内当挿入された製品の端部（耳部）を特殊 形状の回転门板で折り込む装置であり, 製品の寸法に 追従して耳折円板を移動させ安定した耳折りを行う。 装置は自重バランス調整を行い，必要以上の押し付け 力を加えないようにしている。

\section{7 予加圧パート}

前工程での耳折りをさらに安定させ, 次工程での外 当紙貼付け用の糊を耳折部に吹き付ける装置である。 製品は 2 本の受ロールで支持され, 加圧円板には，ヒ 一夕，糊吹き付け用ガンを設置している。糊吹き付け を安定させるため, 製品端面より，吹き付けガンまで の距離を一定に保ち, 製品を回転させながら, 耳部に 糊を吹き付ける。

外当紙貼付け用糊は，コールドグルーが一般的に使 用されているが，ホットメルトを使用することも可能 である。予加压時間, 糊吹付け時間, ガン吹付け距離 は, タッチパネルで変更できるようにしている。

また，ユーザーの要求によっては，製品識別用マー
ク吹き付け装置を上部に設置できるようにしている。 マーキングの色は一般的には, 5 色までが多い。マー キングのパターンは単独作動及び，上位データによる 作動ができるようにしている。

\section{8 外当紙貼付パート}

外当紙を端面部に貼付ける装置で，外当紙にはクラ フトライナーを使用する。外当紙貼付円板はヒー夕を 内蔵し, 圧着乾燥を行う装置である。

高速化が進むとともに，端面に糊付けされた製品に外 当紙を短時間で圧着，乾燥しなければならなくなった。 今まで製品と外当紙の間にたまった空気を逃がす良い 方法が無く, 高速で加圧すると包材が裂けたり, 耳が 膨らむといったトラブルが起こり，高速化に大きな支 障となっていたが，加圧円板移動をサーボモーター制 御で行い, 高速にて移動し, 静かに圧着することで解 消した。

外当紙供給装置は, 内当紙供給装置と同様に, 処理 能力，設置場所により組み合わせる。

\section{9 ラベル貼りパート}

今まで人手によりラベルを発行し，製品に貼付けて いたが，上位デー夕通信が採用されてから，オンライ ンでラベル発行が行われるようになり，貼り付けも自 動化されてきた。ラベルは一般紙，タック紙等が用い られる。

一般紙の場合，発行されたラベルに糊を塗布し，貼 付け装置で胴面及び，端面に貼り付ける。ラベル貼付 位置は，製品中央基準と端面基準の両方がある。多種 類のラベル用紙を製品に使い分ける場合，ラベルプリ ンターを増すことにより多種類の製品を処理すること ができる。

\subsection{0 各パートの製品の取扱い}

製品は各パートへ転送で移動するため，取扱いには 十分注意が必要である。製品は各々工程完了後, 次工 程パートへ転送する。この際, 製品の蛇行, 衝撃は卜 ラブルの原因となるため, 出来るだけ安定した転送を 行わなければならない。

製品は 2 本の受ロールで支持され，転送する際の方 向性を安定させている。受ロールは, キッカーロール， クッションロールを兼用させ, クッションロールの作 動制御は, 製品重量, 製品径により行い, 製品に衝撃 を与えないように工夫している。

クッション压の強弱は製品重量で，クッション動作 時間は製品径の大小で切替えをしている。クッション 動作時間は夕ッチパネルで変更できるようにしている。 


小笠原武

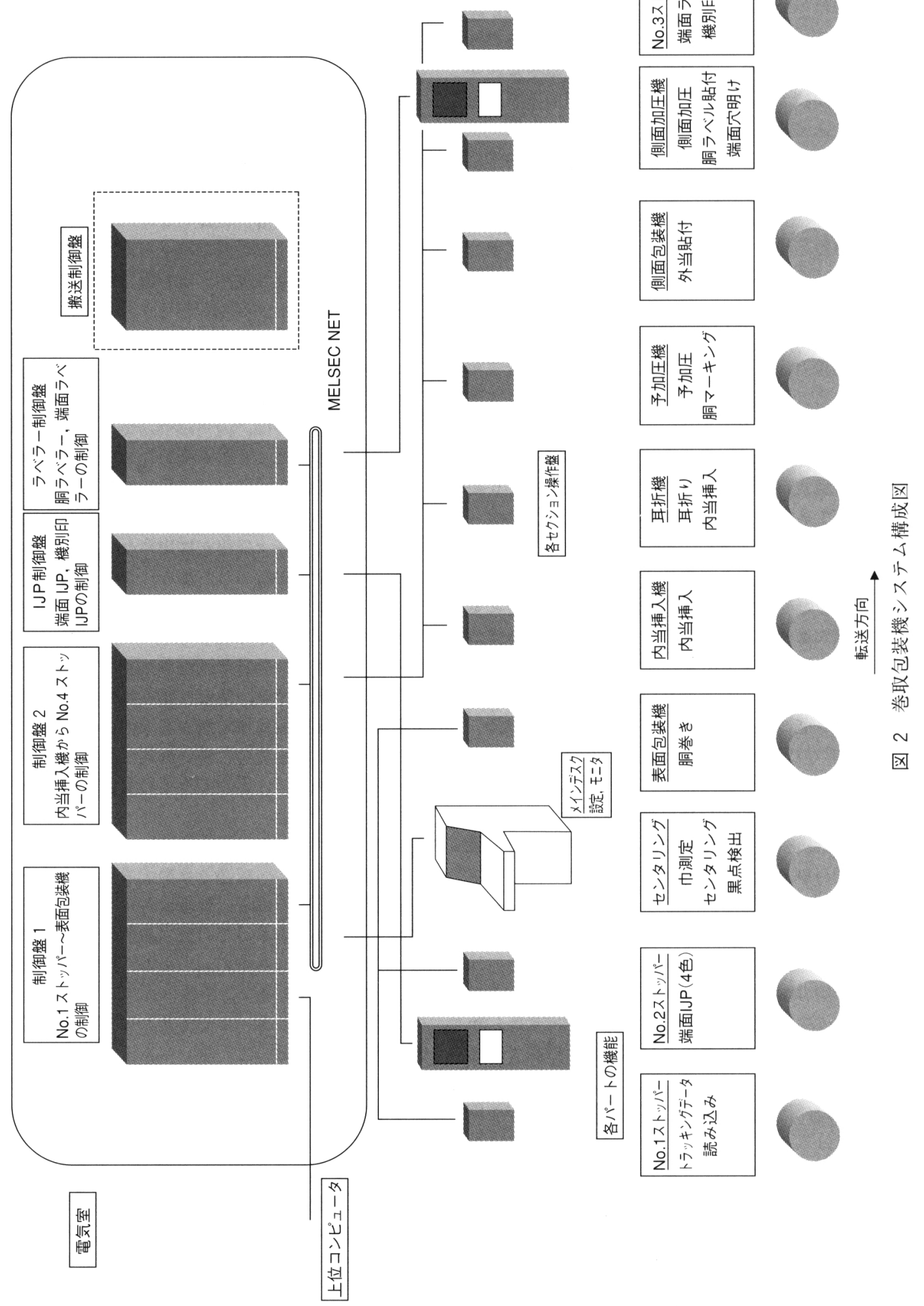




\section{4. 制御について}

本機では，空压，油压，電気制御がさまざまな用途 に使用されている。主なものとしては, 受ロールクッ ション制御，アンリールブレーキ圧制御，胴巻き包装 速度制御，ランダム製品サイズへの各装置の制御であ る。胴卷部, 側面包装プログラム設定, データトラッ キング, 故障モニター, 異常表示等が夕ッチパネルに よって，簡単に変更又は監視ができるようにしている。 これら，デジタル化された制御により熟練した運転 者でなくても，比較的短期間に巻取包装機を運転する ことができる。

\section{5. システムについて}

全自動卷取包装機の制御は，初期の頃は 1 台のシー ケンサにより行われるのがほとんどであったが，最近 の大型機になると, 2 台あるいは，それ以上必要とな る(オプションにより異なる)。図 2 に巻取包装機の
システム構成図を示す。

基本的には, リンクされた 2 台のシーケンサにより包 装機は制御される。ラベラー・IJP 等の装置は，オプ ションとして個々のシーケンサをリンクさせる構成と なっている。各装置の設定, モニターは夕ッチパネル で行われる。ラベラー・IJP のパソコンは印字フォー マットの作成, 表示, プリンター・ヘッド等へのデー 夕送信を行う。先にも記したように，上位コンピュー 夕とのリンクにより，多種類の包装がオンラインで自 動化されるようになった。

\section{6. おわりに}

巻取包装機の現状について概要を記したが，今後仕 上加工部門のオンライン化が進められ，さらに機械の 自動化が要求されるであろう。

当社は今後とも, 高い信頼性, 操作性, 安全性を備 えた機械の開発に努めてゆきたいと考えている。 